\section{ダイヤモンド深紫外 LED}

Deep UV LED Using Diamond

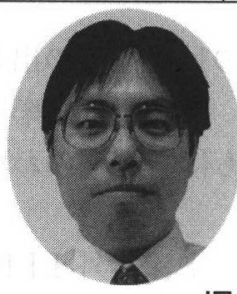

1967年生，1993年東京 大学大学院工学系研究 科物理工学専攻修士課 程修了. 現在, 東京力 又侏 R\&D 企画部フロ ンティア研究所にてタ イヤモンド関連技術開 発に従事.

堀内 賢 治 Kenji Horiuchi
ネルギー）の大きい材料，いわゆるワイドギャップ材料 を使うことが必要になる.このバンドギャップが $5.47 \mathrm{eV}$ と大きいダイヤモンドでは，対応する波長である $227 \mathrm{~nm}$ 程度までの深紫外線発生が可能ということになる. 図 1 にわれわれの作製したダイヤモンド LED の発光スペク トル (室温での電流注入) と, その発光の様子（通常の デジタルカメラによる撮影）を示す. 発光の主ピークは 波長 $235 \mathrm{~nm}$ 付近にあり, この波長は他材料と比較して飛 躍的に短い(図 2 ). バンドギャップの值より $8 \mathrm{~nm}$ ほど 長波長側だが,これは後に説明する発光機構（自由励起 子再結合発光)のためである。これまでに最大で出力 $17 \mu$ W, 外部量子効率 $0.032 \%$ という值が得られている5). 写 真に写っている可視発光は結晶欠陥に起因しており，現

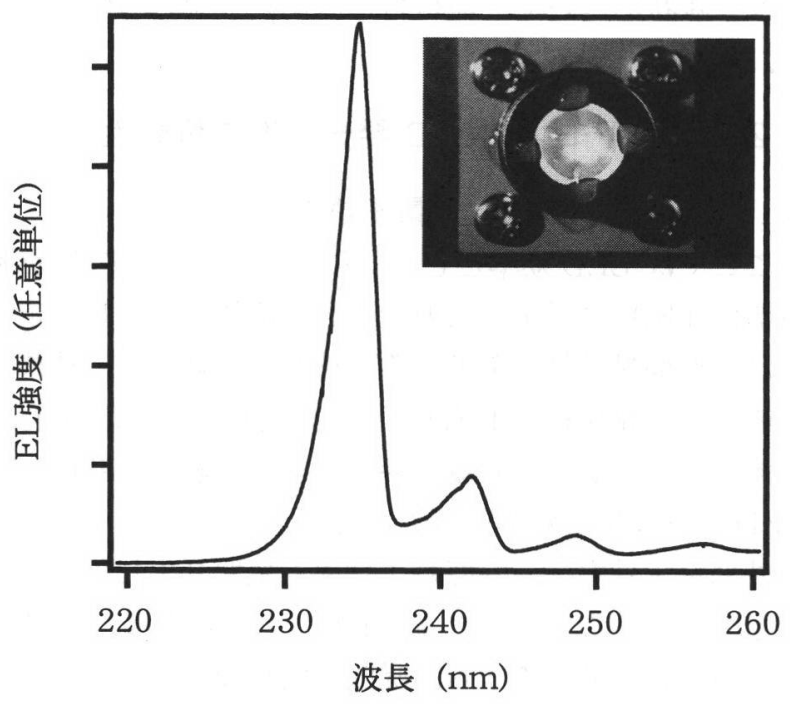

図 1 ダイヤモンド LED の紫外発光スペクトル. 写真は可 視発光の様子を撮影したもの

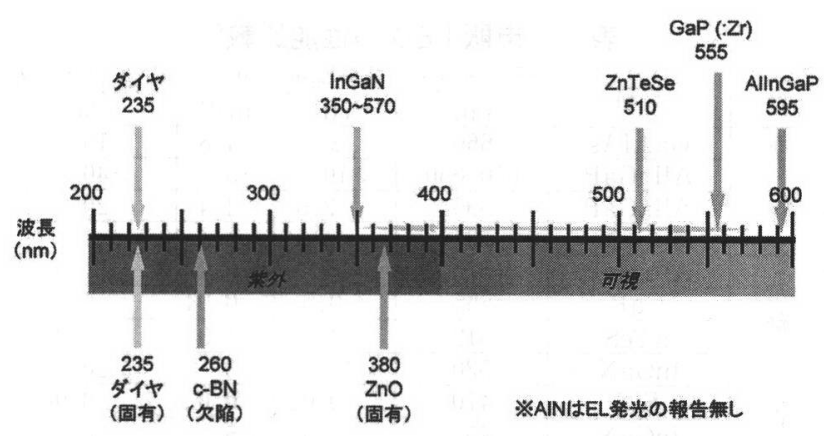

図 2 ワイドギャップ半導体の特性值比較 
在でも紫外発光の10倍程度の出力となっている.この可 視発光の低減は，紫外発光効率・出力の向上，駆動電圧 の低減などとともに，現在のわれわれの主目標となって いる.

このダイヤモンド深紫外 LED の応用先としては，ま ずその短波長性を直接的に活用できる分野として，殺 菌・半導体微細パターン検査・各種研究分析用途などに おける光源を想定している，さらに，十分な効率向上が 達成できた場合には，蛍光体による紫外一可視光変換に よる各種照明光源への応用も考之られる，上記ダイヤモ ンドの発光波長は，蛍光灯に用いられている水銀輝線の $254 \mathrm{~nm}$ に近く, 膨大な開発蓄積のある従来蛍光材料のほ とんどをそのまま用いることが可能である．また，ダイ ヤモンドは炭素単体の結晶であるために廃棄問題がな い.LEDが一般的に持つメリット一長寿命，堅牢性，低 駆動電圧など一を加味して考えれば，短期での白熱灯 · 蛍光灯代替は困難だが，ニッチ(すきま市場)での実用化 は可能性がある。

紫外光の直接応用を考之るにせよ，可視光変換応用を 考之るにせよ，実用化に向けて最も重要な指標は発光効 率である. 本稿では, ダイヤモンド LED の発光効率の可 能性と現状について，他材料との比較を交えつつ紹介す る.

\section{2.ダイヤモンド LED 発光効率の可能性}

\section{1 外部量子効率と内部量子効率}

ここでは LED 効率として，入力したキャリア数(駆動 電流に比例）に対する出力光子数の個数の比として定義 される外部量子効率を考之る. 外部量子効率は，技術段 階の異なる諸材料の LED としての可能性の比較を行い やすい指標だからである，参考として，表 2 に各種市販 LEDの外部量子効率6)を示した。

外部量子効率は, 内部量子効率と光取り出し効率の積 として考えることができる. 光取り出し効率は, LED 内 部で得られた発光のうち，吸収・散乱などを受けずに外 部に有効に取り出せる光子の割合であり, 加工・パッケー ジ・光学系などの設計によるところが大きい。近年の LED 高輝度化の流れの中で大幅な改善が進み，例之ば

表 2 市販 LED の性能比較 ${ }^{6)}$

\begin{tabular}{|c|c|c|c|c|c|}
\hline 色 & 材料 & $\begin{array}{c}\text { ピーク波長 }_{(\mathrm{nm})} \\
.\end{array}$ & $\begin{array}{l}\text { 発光強度 } \\
(\mathrm{cd})\end{array}$ & $\begin{array}{l}\text { 出力 } \\
(\mathrm{mW})\end{array}$ & $\begin{array}{c}\text { 外部量子効率 } \\
(\%)\end{array}$ \\
\hline 赤 & GaAIAs & 660 & 2 & 4.8 & 15 \\
\hline \multirow{3}{*}{ アンバ } & AlInGaP & $610-650$ & $>10$ & $>5$ & $>40$ \\
\hline & AlInGaP & 595 & 2.6 & 4.4 & $>20$ \\
\hline & InGaN & 594 & 4.5 & 1.4 & 3.3 \\
\hline \multirow{4}{*}{ 緑 } & AlInGaP & 570 & 1 & 0.4 & 1.0 \\
\hline & $\mathrm{GaP}$ & 555 & 0.5 & 0.04 & 0.1 \\
\hline & ZnTeSe & 512 & 4 & 1.3 & 5.3 \\
\hline & InGaN & 520 & $>12$ & $>3$ & $>20$ \\
\hline \multirow{2}{*}{ 青 } & $\mathrm{SiC}$ & 470 & 0.02 & 0.02 & 0.04 \\
\hline & InGaN & 450 & $>2.5$ & $>5$ & $>20$ \\
\hline 紫外 & InGaN & 371 & - & 0.5 & 7.5 \\
\hline
\end{tabular}

AlInGaP 系アンバー色 LED では50\%以上の值が得ら れている7).

一方, 内部量子効率は, LED の発光機構, 材料の結晶 性などで決まる発光部でのキャリア一光子変換効率であ る. ある発光機構の内部量子効率 $\eta$ は, 輻射 (発光) 寿 命 $\tau \mathrm{R}$ と非輻射 (非発光) 寿命 $\tau \mathrm{NR}$ で次式(1)のように表 される.

$$
\eta=\frac{\tau_{\mathrm{R}}^{-1}}{\tau_{\mathrm{R}}^{-1}+\tau_{\mathrm{NR}}{ }^{-1}}=\left[1+\frac{\tau_{\mathrm{R}}}{\tau_{\mathrm{NR}}}\right]^{-1} \cdots \cdots(1)
$$

$\tau_{\mathrm{R}}$ は物質・発光機構固有の值であり, 短いほど発光が起 こりやすいことを表す。一方㓋注，目的の発光機構以外 の経路で緩和していく効果を総合した值であり，材料・ デバイス作製の技術レベルによって制約される.内部量 子効率 $\eta$ を大きくするためには, ${ }_{{ }_{\mathrm{R}}}$ が ${ }_{\mathrm{NNR}}$ と比べてできる だけ短い材料を選ぶか，もしくは㓋茂長くなるよう，材 料合成・デバイス作製技術を向上させていくことが必要 である。

\section{2. 発光機構による効率の差}

ほとんどの LED では，伝導帯の電子と価電子带の正 孔との再結合 (バンド間遷移) を発光機構としている. ところが, その輻射寿命 $\tau_{\mathrm{R}}$ は, 電子一正孔が再結合して光 子を放出する際にフォノンの介在を必要とする間接遷移 型半導体と，フォノン介在が不要な直接遷移型とで大幅 に異なっている. 前者の典型的 $\tau_{\mathrm{R}}$ は $100 \sim 1000_{\mu \mathrm{sec}}$, 後者

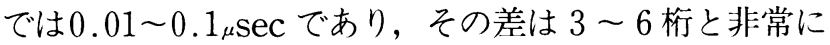
大きい，式(1)からわかるように，直接型と比較したとき の間接型のバンド間㟟移の内部量子効率 $\eta$ は, 非輻射寿 命 $\tau_{\mathrm{NR}}$ が同程度であるならば， ${ }_{\mathrm{NR}}$ のオーダー差だけ小さ いことになる，Si や Geがそのままでは LED に適用さ れない理由がこれであり，表 2 の LEDの中でも間接型 の $\mathrm{SiC}, \mathrm{GaP}$ は外部効率0.01〜0.1\%しか得られていな い.

ダイヤモンドも間接遷移型半導体だが，実はその発光 機構は通常のバンド間遷移ではなく，自由励起子（静電 気力で引き合ってエネルギー的に安定化した電子一正孔 ペア）という状態を経由している，励起子は通常の半導 体では熱的に非常に不安定で，非常な低温でしか観測さ れないが，多イヤモンドでは例外的に室温下でも安定に

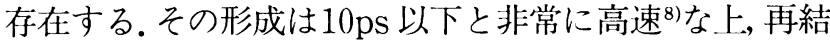
合輻射寿命も $2.3 \mu \mathrm{sec}^{9}$ と十分に短い. $\mathrm{SiC} や \mathrm{GaInN}$ 系 LED では励起子過程の発光への寄与の可能性があると されているが，ダイヤモンドのようにほぼ完全に励起子 系のみの発光が観測されているという例は, 既往の LED にはない。

上記 3 つの機構の比較を図 3 に示した. 矢印の太さは, 各過程が起きる時間のオーダーを概念的に示しており, 太いほど短時間で効率よくその過程が進むことを示して いる.この結果は，もしダイヤモンド LEDにおける自由 


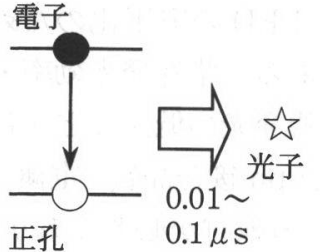

(a) 直接遷移型

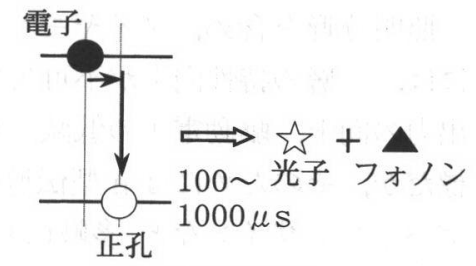

(b) 間接遷移型
電子

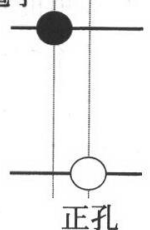

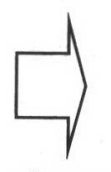

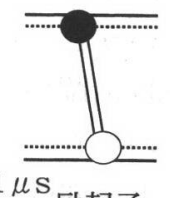

励起子

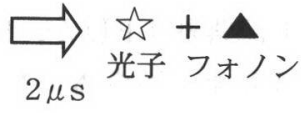

(c) ダイヤモンド（自由励起子再結合発光）
励起子再結合の非輻射寿命 $\tau_{\mathrm{NR}}$ が他半導体材料程度 $(\mu \mathrm{sec}$ オーダーと推定される）に抑制できれば，内部量子効率 として $10 \%$ 以が期待できることを意味している. 実際

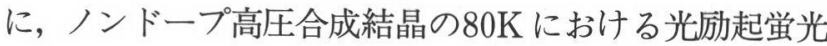
時間分解測定では，量子効率 $2.27 \%$ という值が実測され ている9). 自由励起子再結合発光というユニークな発光 機構を用いるダイヤモンドでは，実用に十分な効率を有 する紫外 LED が実現できる可能性があるといえる。

\section{3. ダイヤモンド LED の作製と評価}

半導体品質のダイヤモンド結晶の合成法としては，高 温高圧合成法と気相合成 (CVD) 法とがある。前者は, 大型プレス装置の $5 \mathrm{GPa}, 1500^{\circ} \mathrm{C}$ という条件下で金属融 剂中に炭素を溶解させてから, 再結晶法でバルク結晶を 作製する方法である，後者は，真空チャンバー内に水素 プラズマを発生させ，炭素を含むガスを導入して薄膜を 基板上に堆積する方法である。量産を考える場合には CVD 法でのへテロエピタキシャル成長（異種材料基板 への単結晶膜作製）が望ましいが，現状での結晶品質な どの制約から，われわれは高圧合成基板上への CVD ホ モエピタキシャル成長を用いている.

ダイヤモンド LED 作製の手順は，以下のとおりであ る.

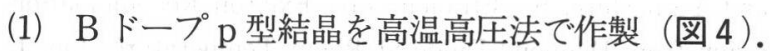

(2) 上記結晶を $2 \times 2 \times 0.4 \mathrm{~mm}^{3}$ の板状に研磨加工し て，基板を準備。

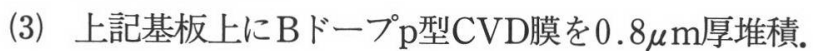

(4) $\mathrm{S}$ ドープ $\mathrm{n}$ 型 CVD 膜を $1.5 \mu \mathrm{m}$ 厚堆積.

（5） 反応性イオンエッチングを $4 \mu \mathrm{m}$ 厚行い, 素子分離。

(6) $\mathrm{Ti} / \mathrm{Au}$ 電極を $\mathrm{n}$ 型アイランド (非エッチング部分) 上と $\mathrm{p}$ 型下地 (エッチング部分) 上とに作製，アニー ル(付着力強化・オーミック接触を目的とした熱処理). こうして作製した LED の断面模式図を，図５に示す.
LED の発光部となる pn 接合部の面積は, $100 \times 100 \mu \mathrm{m}^{2}$ であり， 1 基板上に約80個の LED が作りこまれている。 $\mathrm{p}$ 型基板上に, 同じ $\mathrm{p}$ 型 CVD 膜を緩衝層として堆積し ているのは, 発光効率に重大な影響を及ぼす pn 接合面 の結晶欠陥の密度低減を目指したからである。

この LED の典型的な発光スペクトルを図 6 に示す. 動作条件は室温での自然放熱, $5 \mathrm{~mA}$ 定電流駆動で, 駆 動電圧は約 $30 \mathrm{~V}$ である. 波長 $235 \mathrm{~nm}$ に, 非常に強い自由

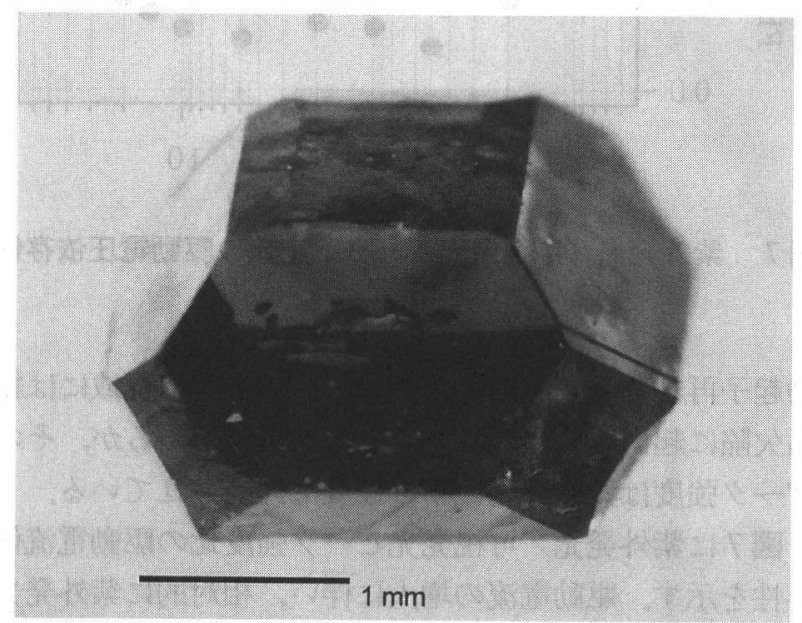

図 4 高温高圧合成 $\mathrm{B}$ ドープ $\mathrm{p}$ 型ダイヤモンド結晶の光 学写真

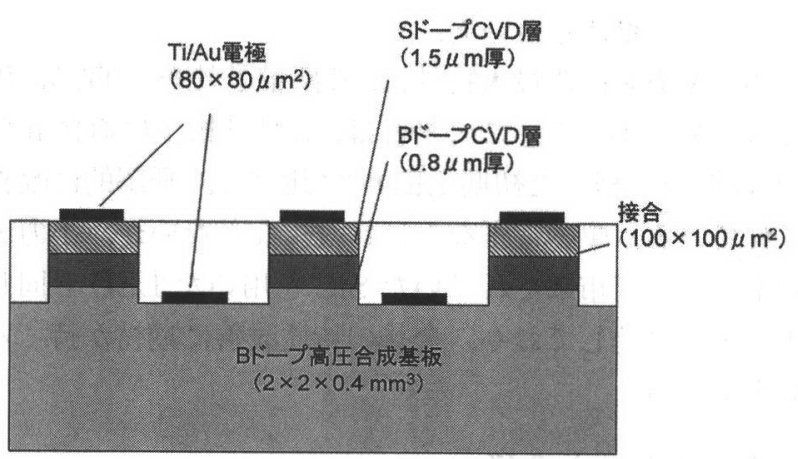

図 5 ダイヤモンド LED 断面構造の模式図

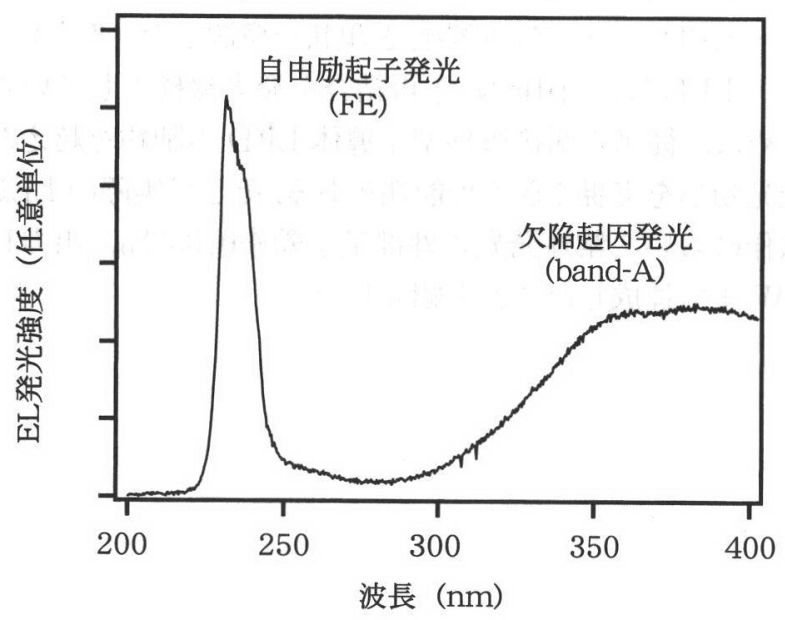

図 6 試作ダイヤモンド LED の発光スペクトル 


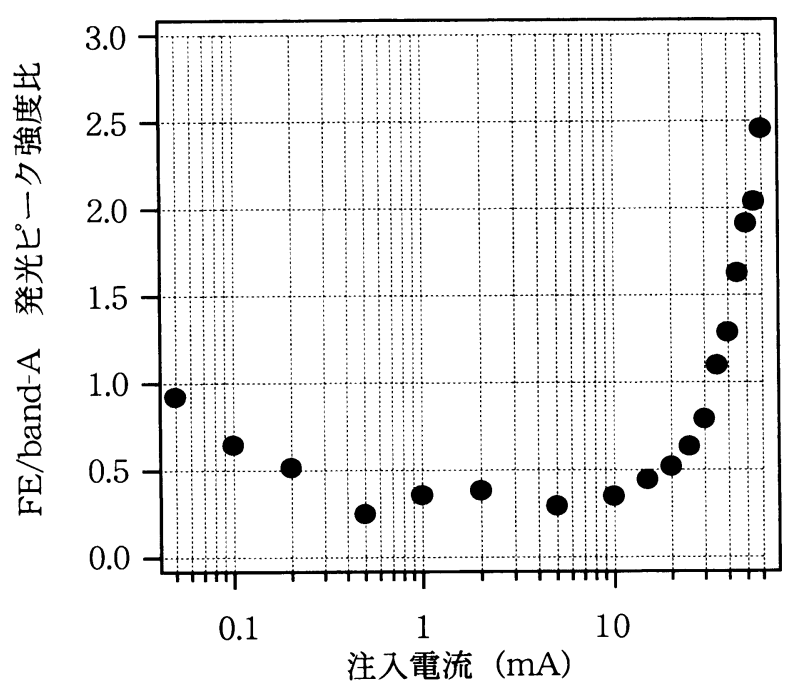

図 7 紫外発光 /可視発光ピーク強度比の駆動電圧依存性

励起子再結合発光が得られている. 一方, 可視域には結 晶欠陥に起因する幅の広い発光帯が現れているが，その ピーク強度は紫外発光の半分程度に抑制されている。

図 7 に紫外発光 $/$ 可視発光ピーク強度比の駆動電流依 存性を示す. 駆動電流の増大に伴い, 相対的に紫外発光 強度が増大していることがわかる。この挙動は, $\mathrm{p}$ 型緩衝 層により, この程度の電流密度で可視発光が飽和するレ ベルまで pn 接合部付近の結晶欠陥密度が低減されたこ とによると推測している。

$10 \mathrm{~mA}$ 駆動時の最大特性は, 外部量子効率 $0.032 \%$, 出 力 $17 \mu \mathrm{W}$ であった。 この特性は, $\mathrm{p}$ 型基板上に直接 $\mathrm{n}$ 型 CVD 層を堆積した初期 $\mathrm{LED}^{11)}$ に比べて, 飛躍的に改善 されている，駆動電圧などは比較にならないが，出力・ 効率はかつて市販されていた $\mathrm{SiC}$ を用いた LED と同じ オーダーに達しており, 今後の特性改善に期待が持てる 結果である.

\section{4.まとめと今後}

以上, 波長 $235 \mathrm{~nm}$ という深紫外光を発生するダイヤモ ンド LEDについて, 可能性と現状を概説した.ダイヤモ ンド LEDは, 自由励起子再結合を発光機構としている ために, 従来の間接遷移型半導体 LED の制約を超えた 発光効率を実現できる可能性がある.そして実際の LED 試作において紫外発光の外部量子効率 $0.032 \%$, 出力 17 $\mu \mathrm{W}$ まで達成したことを紹介した。
照明分野を含め，ダイヤモンド LED の実用化のため には，一層の特性向上が不可欠である。紫外発光効率・ 出力の向上, 駆動電圧の低減, 可視発光の低減などが目 標だが，そのためには $\mathrm{n}$ 型伝導性・pn 接合品質・電極・ デバイスデザインなど,多岐にわたる検討が必要であり， その達成は決して容易ではない。しかし楽観的な見方を するならば，検討の余地が多いだけに性能向上の可能性 も数多く残されているということもできよう.ダイヤモ ンド梁紫外 LED が, LED 活躍の場をさらに広げ，さら には究極の半導体ともいわれるダイヤモンドの電子デバ イス応用の先鞭となることを期待している.

なお末筆ではあるが, 本研究は社内外の多くの方々の 御協力による成果であり，心から感謝申し上げて拙稿の 締めくくりとしたい.

\section{参考文献}

(1) 平山秀樹: 窒化物半導体からの紫外高輝度発光と $300 \mathrm{~nm}$ 带発光 素子への応用，オプトロニクス226, pp.145-151（平12）。

(2) 吉田貞史：ワイドギャップ半導体一ハードエレクトロニクス色 発光を目指して一, 電子情報通信学会誌79, pp.1219-1228 (1996).

(3) Koizumi, S., Kamo, M., Sato, Y., Ozaki, H. and Inuzuka, T. : Growth and Characterization of Phosphorous Doped \{111\} Homoepitaxial Diamond Thin Films, Appl. Phys. Lett. 71, pp. 1065-1067 (1997).

(4) Sakaguchi, I., N.-Gamo, M., Kikuchi, Y., Yasu, E., Haneda, H., Suzuki, T. and Ando, T. : Sulfur: A Donor Dopant for N-type Diamond Semiconductors, Phys. Rev B60, R2139-2141 (1999).

(5) 堀内, 河村, 岡島, 井出, 石倉, 中村：ダイヤモンド樑紫外 LED の特性向上, 第63回秋季応用物理学会子稿集 p. $501,16 \mathrm{a}-Z \mathrm{R}-5$ (平 14).

(6) 田口常正：高輝度 LED の技術革新と白色 LED 照明システムの 展望, オプトロニクス228, pp.112-119 (平12).

（7）山田範秀：可視光 LED の高効率化, 応用物理68, pp.139-145(平 11).

(8) Nagai, M., Shimano, R., Horiuchi, K. and Kuwata-Gonokami, M. : Phys. Rev. Lett. (submitted).

(9) Fujii, A., Takiyama, K., Maki, R. and Fujita, T. : Lifetime and Quantum Efficiency of Luminescence due to Indirect Excitons in a diamond, J. Lumin., 94-95, pp.335-357 (2001) .

(10) Horiuchi, K., Kawamura, A., Ide, T., Ishikura, T., Nakamura, K. and Yamashita, S. : Efficient Free-Exciton Recombination Emission from Diamond Diode at Room Temperature, Jpn. J. Appl. Phys. 40, L275-278 (2001). 